\title{
METAMICT ZIRCON FROM MOZAMBIQUE
}

\author{
RAGNAR TÖRNROOS
}

\begin{abstract}
TÖRNROOS, RAGNAR, 1985: Metamict zircon from Mozambique. Bull. Geol. Soc. Finland 57, Part 1-2, 181-195.

Metamict zircon from granite pegmatites of Zambézia, Mozambique has been studied by annealing, microprobe, X-ray diffraction, DT and TG analysis, and IR spectroscopy. The specimens are contaminated by epitaxially intergrown xenotime. It is presumed that the lanthanoides, occur in the xenotime phase and only sparsely in the zircon. Some $U$ and $T h$ are evenly distributed throughout the completely metamict parts of the zircon but elsewhere only in minor amounts. Around the metamict parts they build up their own uranium and thorium phases or occur as fracture fillings. Th prefers the xenotime phase and $U$ the zircon.
\end{abstract}

Key words: zircon, metamict, X-ray, DTA, TGA, IR-spectroscopy, pegmatite mineral, metamictisation, Zambézia, Mozambique.

Ragnar Törnroos: Geological Survey, SF-02150 Espoo, Finland.

\section{Introduction}

The zircon specimens that form the material of this study are from the district of Zambézia, Mozambique, some of them being the same as used for the compositional determinations and mineral chemical studies by Törnroos (1982). The sample treatments are described in the above paper. These specimens are in a highly metamict state and offer a good opportunity to study the metamictisation process. The results obtained by microprobe, X-ray diffraction, DT and TG analysis and by IR spectroscopy are summarised in this paper.

Earlier microprobe studies did not reveal appreciable amounts of uranium and thorium in the samples; wet chemical and XRF analyses also showed a lack of these elements (Törnroos 1982). The results were puzzling because meta- mictisation in minerals is generally attribute $a$ to the radiation damage produced by radioac ive decay of thorium and uranium (i.e. Mitsiell 1973). A combined microprobe - scanning electron microscope (electron probe instrum $\mathbf{n}$, EPI) was recently made available to the author and the specimens were reanalysed. The new results obtained are the subject of this article.

\section{Materials}

The material for this study consists of 16 metamict zircon specimens of Zambézia granite pegmatites. The specimens labelled LM were obtained from the collections of the Geology Department of the University of Maputo (formerly Lourenço Marques) (courtesy: professors J. M. Correia Neves and J. E. Lopes Nunes). 
The remaining specimens were collected in the field by the late professor Th. G. Sahama, who placed all the specimens at the author's disposal. The numbering of the specimens used in this paper, together with the localities from which they originate, is given in the legend to Table $2 \mathrm{~A}$.

Almost all of the specimens appear as fanshaped aggregates of subparallel idiomorphic to hypidiomorphic crystals. The different degree of metamictisation is clearly seen under the microscope. Completely or almost completely metamict areas in the central part of the zircon crystals, have a glassy appearance and vary in size in the different specimens; some specimens are in an almost wholly glassy condition. The zircon specimens display intense fracturing of various types. Along larger cracks, which build up a pervasive network in the specimens, the zircon is anisotropic and hence better crystallised (Fig. 6 A). Backscattered electron images (BEI) also reveal the presence of an intricate network of narrow ( $<1 \mu \mathrm{m}$ width) fractures in the zircon specimens.
The fractures are either void or filled with various materials: xenotime, secondary uranylbearing aggregates, iron oxides or hydroxides, REE-bearing compounds and zirconium-thorium-uranium compounds, sometimes also thorianite (Fig. 5). In some zircon samples, fillings or intergrowths of columbite and related minerals also occur.

The extinction is undulatory; perpendicular to the c-axis a set of subparallel cracks occurs throughout the aggregates (see Fig. $6 \mathrm{~A}$ ). The smallest cracks encountered resemble dessication cracks and occur in the most metamict specimens, where the glassy parts are very like a gel (Fig. 6 B).

\section{Xenotime contamination}

The Zambézia zircon samples are severely contaminated by epitaxially intergrown xenotime. Since X-ray diffraction makes it possible to estimate rapidly the amount of xenotime in

Table 1. The abundance of xenotime in zircon specimens from Mozambique, determined by means of X-ray diffraction.

\begin{tabular}{|c|c|c|c|c|c|}
\hline \multirow[t]{2}{*}{ No* } & \multirow{2}{*}{$\frac{\mathrm{I}_{\mathrm{Zir}}}{\mathrm{I}_{\mathrm{Xen}}}$} & \multicolumn{2}{|c|}{ X-ray diffraction } & \multicolumn{2}{|c|}{ wet chemical analysis } \\
\hline & & $\begin{array}{c}\text { wt } \% \\
\text { xenotime }\end{array}$ & $\begin{array}{c}\text { corresp. } \\
\text { wt } \% \quad \mathrm{P}_{2} \mathrm{O}_{5}\end{array}$ & wt $\% \mathrm{P}_{2} \mathrm{O}_{5}$ & $\begin{array}{l}\text { corresp. } \\
\text { xenotime }\end{array}$ \\
\hline 1 & 100 & $<2$ & $<0.7$ & 0.56 & 1.5 \\
\hline 2 & 39.5 & $<2$ & $<0.7$ & $* *$ & \\
\hline 3 & 0.76 & 63.0 & 24.3 & $* *$ & \\
\hline 4 & 65.0 & $<2$ & $<0.7$ & 1.00 & 2.6 \\
\hline 5 & 15.0 & 6.6 & 2.5 & 1.93 & 5.0 \\
\hline 6 & 12.8 & 8.3 & 3.2 & 3.86 & 10.0 \\
\hline 7 & 6.1 & 17.0 & 6.6 & $* *$ & \\
\hline 8 & 16.2 & 6.0 & 2.3 & 2.41 & 6.2 \\
\hline 9 & 45.0 & $<2$ & $<0.7$ & 0.50 & 1.3 \\
\hline 10 & 35.6 & $<2$ & $<0.7$ & $* *$ & \\
\hline 11 & 11.1 & 9.7 & 3.7 & ** & \\
\hline 12 & 23.1 & 3.2 & 1.2 & 0.99 & 2.6 \\
\hline 13 & 34.0 & $<2$ & $<0.7$ & 1.62 & 4.2 \\
\hline 14 & 8.7 & 12.4 & 4.8 & $* *$ & \\
\hline 15 & 24.2 & 2.6 & 1.0 & $* *$ & \\
\hline 16 & 20.6 & 3.5 & 1.3 & 0.56 & 1.5 \\
\hline
\end{tabular}

* numbers according to legend in Table $2 \mathrm{~A}$

** no bulk analyses available. 
Table 2 A. Microprobe analyses of anisotropic parts (interference colour $>$ yellow) in metamict zircon from Mozambique.

\begin{tabular}{|c|c|c|c|c|c|c|c|c|c|c|c|c|c|c|}
\hline $\mathrm{No}^{1}$ & 1 & 3 & 5 & 6 & 7 & 8 & 9 & 10 & 11 & 12 & 13 & 14 & 15 & 16 \\
\hline $\mathrm{SiO}_{2}$ & 30.5 & 29.9 & 29.5 & 30.1 & 29.9 & 28.9 & 29.0 & 27.4 & 31.5 & 29.7 & 23.5 & 28.4 & 28.8 & 29.6 \\
\hline $\mathrm{ZrO}_{2}$ & 60.3 & 58.5 & 59.6 & 58.9 & 58.8 & 56.8 & 57.4 & 52.0 & 59.6 & 55.0 & 57.3 & 53.0 & 47.9 & 49.4 \\
\hline $\mathrm{HfO}_{2}$ & 2.57 & 3.88 & 4.44 & 4.84 & 5.53 & 5.40 & 5.47 & 6.60 & 8.20 & 8.79 & 10.8 & 14.2 & 17.2 & 19.6 \\
\hline $\mathrm{FeO}^{*}$ & 0.15 & 0.84 & 0.20 & 0.36 & 0.20 & 1.50 & 0.05 & 0.05 & 0.10 & 0.08 & 1.22 & 0.07 & 0.02 & 0.32 \\
\hline $\mathrm{CaO}$ & 0.02 & 0.60 & 0.16 & 0.04 & 0.16 & 0.51 & n.d. & 0.02 & 0.01 & 0.14 & 0.10 & 0.03 & 0.10 & 0.37 \\
\hline $\mathrm{P}_{2} \mathrm{O}_{5}$ & 0.05 & 0.13 & 0.37 & 0.99 & n.d. & 1.55 & 0.14 & n.d. & n.d. & 0.59 & 0.34 & 1.04 & n.d. & 0.20 \\
\hline $\mathrm{Y}_{2} \mathrm{O}_{3}$ & 0.34 & 0.78 & 0.84 & 0.51 & n.d. & 1.00 & 0.53 & n.d. & n.d. & 0.86 & 1.04 & 0.97 & n.d. & 0.04 \\
\hline $\mathrm{Ln}_{2} \mathrm{O}_{3}$ & 0.34 & 1.12 & 0.80 & 1.27 & 0.76 & 0.88 & $* *$ & 0.56 & 0.22 & 0.96 & 0.74 & $* *$ & 0.18 & 0.40 \\
\hline $\mathrm{ThO}_{2}$ & 0.03 & 0.48 & 0.11 & n.d. & n.d. & 0.44 & n.d. & 0.21 & n.d. & 0.33 & 0.44 & 0.11 & 0.12 & n.d. \\
\hline $\mathrm{UO}_{2}$ & 0.50 & 1.28 & 1.44 & 0.55 & 0.25 & 1.44 & 0.95 & 0.93 & 0.02 & 0.67 & 1.35 & 0.21 & 0.37 & 0.12 \\
\hline Total & 94.46 & 97.51 & 97.46 & 97.56 & 95.60 & 97.91 & 93.54 & 87.77 & 99.38 & 97.12 & 96.83 & 98.03 & 94.69 & 100.05 \\
\hline
\end{tabular}

Cation per cent

\begin{tabular}{|c|c|c|c|c|c|c|c|c|c|c|c|c|c|c|}
\hline $\mathrm{Si}$ & 49.80 & 38.11 & 47.94 & 48.42 & 49.17 & 46.26 & 48.99 & 49.70 & 49.24 & 48.91 & 41.13 & 47.45 & 50.20 & 49.09 \\
\hline $\mathrm{Zr}+\mathrm{Hf}$ & 49.21 & 47.69 & 49.29 & 48.42 & 49.75 & 46.80 & 49.91 & 49.41 & 49.79 & 48.30 & 54.30 & 49.94 & 49.28 & 49.23 \\
\hline $\mathrm{Fe}$ & 0.21 & 1.13 & 0.27 & 0.48 & 0.28 & 2.01 & 0.07 & 0.08 & 0.13 & 0.11 & 1.79 & 0.10 & 0.03 & 0.45 \\
\hline $\mathrm{Ca}$ & 0.04 & 1.03 & 0.28 & 0.07 & 0.29 & 0.88 & nil & 0.02 & 0.02 & 0.25 & 0.19 & 0.05 & 0.19 & 0.65 \\
\hline $\mathrm{P}$ & 0.07 & 0.17 & 0.51 & 1.34 & nil & 2.10 & 0.20 & nil & nil & 0.82 & 0.48 & 1.47 & nil & 0.28 \\
\hline$Y$ & 0.29 & 0.67 & 0.72 & 0.43 & nil & 0.86 & 0.48 & nil & nil & 0.75 & 0.97 & 0.86 & nil & 0.04 \\
\hline Ln & 0.18 & 0.56 & 0.42 & 0.65 & 0.42 & 0.42 & - & 0.32 & 0.11 & 0.49 & 0.44 & - & 0.10 & 0.22 \\
\hline Th & 0.01 & 0.17 & 0.04 & nil & nil & 0.16 & nil & 0.09 & nil & 0.12 & 0.18 & 0.04 & 0.05 & nil \\
\hline $\mathrm{U}$ & 0.19 & 0.45 & 0.52 & 0.19 & 0.09 & 0.51 & 0.36 & 0.37 & 0.01 & 0.25 & 0.53 & 0.08 & 0.15 & 0.04 \\
\hline $100 \mathrm{Hf}$ & \multirow{2}{*}{2.4} & \multirow{2}{*}{3.7} & \multirow{2}{*}{4.2} & \multirow{2}{*}{4.6} & \multirow{2}{*}{5.2} & \multirow{2}{*}{5.3} & \multirow{2}{*}{5.3} & \multirow{2}{*}{6.9} & \multirow{2}{*}{7.5} & \multirow{2}{*}{8.6} & \multirow{2}{*}{9.9} & \multirow{2}{*}{13.6} & \multirow{2}{*}{17.4} & \multirow{2}{*}{18.8} \\
\hline $\mathrm{Zr}+\mathrm{Hf}$ & & & & & & & & & & & & & & \\
\hline
\end{tabular}

Atomic proportions of lanthanoides based on $\mathrm{La}+\cdots \mathrm{Lu}=100$

\begin{tabular}{|c|c|c|c|c|c|c|c|c|c|c|c|c|c|c|}
\hline $\mathrm{La}$ & 8.0 & 3.5 & nil & 1.1 & nil & 2.0 & $* *$ & 6.9 & 11.2 & 8.3 & 1.9 & $* *$ & nil & 17.2 \\
\hline $\mathrm{Ce}$ & 5.5 & 0.8 & 2.1 & 4.1 & 18.3 & 0.9 & & 7.6 & 15.1 & 3.4 & 7.8 & & nil & 18.0 \\
\hline $\operatorname{Pr}$ & 1.6 & nil & 0.2 & nil & nil & 3.2 & & 2.1 & nil & nil & nil & & 12.9 & 8.7 \\
\hline $\mathrm{Nd}$ & 1.2 & 0.6 & nil & nil & nil & nil & & 1.5 & 0.8 & 0.6 & nil & & nil & 3.0 \\
\hline $\mathrm{Sm}$ & 0.5 & nil & 0.2 & 0.4 & 0.7 & nil & & nil & 0.3 & 0.1 & nil & & 0.2 & 0.2 \\
\hline $\mathrm{Eu}$ & 1.9 & 17.1 & nil & 9.2 & nil & nil & & 7.0 & nil & 4.4 & nil & & nil & 0.1 \\
\hline Gd & nil & 2.9 & 6.4 & 4.1 & 42.5 & 3.8 & & 30.3 & 12.2 & nil & 11.5 & & nil & nil \\
\hline $\mathrm{Tb}$ & 8.0 & nil & 3.4 & nil & 6.7 & 0.2 & & 2.8 & nil & 5.5 & 6.6 & & 15.9 & 1.0 \\
\hline Dy & 20.7 & 7.6 & 35.1 & 11.8 & 30.6 & 10.6 & & 20.7 & 55.6 & 14.0 & 41.9 & & 11.3 & nil \\
\hline \multicolumn{15}{|c|}{ Ho** } \\
\hline Er & 14.4 & 14.4 & 20.5 & 15.3 & 1.7 & 13.5 & & 11.2 & nil & 2.6 & 20.5 & & 59.9 & 36.7 \\
\hline $\operatorname{Tm}$ & nil & 5.8 & 8.6 & 1.8 & nil & 9.3 & & 7.5 & nil & 3.5 & nil & & nil & 14.5 \\
\hline $\mathrm{Yb}$ & 28.7 & 47.1 & 23.4 & 52.3 & nil & 50.1 & & 2.6 & 4.6 & nil & 9.7 & & nil & 0.6 \\
\hline $\mathrm{Lu}$ & 4.7 & nil & nil & nil & nil & 6.4 & & nil & nil & 7.1 & nil & & nil & nil \\
\hline
\end{tabular}

1 Analyses of specimens Nos 2 and 4 are given separately in Tables 4 and 7 .

* = total $\mathrm{Fe}$ as $\mathrm{FeO}, * *=$ not determined, n.d. = not detected.

List of pegmatite localities of the specimens:

No. 1 Boa Esperança, Ribaué. Specimen LM 4627.

No. 2 Namatacunue, Ribaué. Specimen LM 4541.

No. 9 Nachaca, Nauela. Specimen LM 4399.

No. 3 Meco, Nauela. Specimen LM 3189.

No. 4 Guilherme I, Nauela. Specimen LM 4368.

No. 5. Boa Esperança, Ribaué. Specimen LM 5189.

No. 6 Meco, Nauela. Specimen LM 3180.

No. 7 Nuaparra.

No. 8 Meco, Nauela. Specimen LM 3181.

No. 10 Muiane. Specimen 2

No. 11 Ginama. Specimen LM 2269.

No. 12 Muiane. Specimen 4.

No. 13 Boa Esperança, Ribaué. Specimen LM 4423.

No. 14 Rio Maria I. Specimen LM 1423.

No. 15 Muiane. Specimen 1.

No. 16 Muiane. Specimen 3. 
Table 2 B. Microprobe analyses of glassy parts (almost totally metamict) of the Zambézia zircon specimens.

\begin{tabular}{lcccccccccr}
\hline & 5 & 6 & 8 & 9 & 10 & 11 & 13 & 14 & 15 & 16 \\
\hline $\mathrm{SiQ}_{2}$ & 27.4 & 27.4 & 27.1 & 26.1 & 26.9 & 28.2 & 24.0 & 24.5 & 26.1 & 26.2 \\
$\mathrm{ZrO}_{2}$ & 53.9 & 54.2 & 56.7 & 53.9 & 49.6 & 55.4 & 49.7 & 42.7 & 43.6 & 45.3 \\
$\mathrm{HfO}_{2}$ & 3.46 & 4.01 & 5.04 & 5.43 & 5.54 & 6.83 & 8.76 & 12.4 & 16.6 & 19.1 \\
$\mathrm{FeO}^{*}$ & 0.24 & 0.04 & 0.61 & 1.20 & 0.23 & 1.22 & 0.52 & 0.09 & 0.06 & 0.02 \\
$\mathrm{CaO}$ & 1.37 & 0.06 & 1.86 & 0.91 & 0.14 & 0.86 & 0.91 & 1.08 & 0.69 & 0.18 \\
$\mathrm{P}_{2} \mathrm{O}_{5}$ & 1.68 & 1.50 & 1.77 & 1.17 & 0.11 & 1.04 & 0.87 & 3.39 & 0.33 & n.d. \\
$\mathrm{Y}_{2} \mathrm{O}_{3}$ & 2.29 & 2.58 & 1.78 & 2.97 & 0.45 & 0.97 & 1.76 & 3.51 & n.d. & n.d. \\
$\mathrm{Ln}_{2} \mathrm{O}_{3}$ & 1.01 & 3.59 & 1.88 & $* *$ & 0.73 & 0.62 & 0.78 & $* *$ & 0.14 & 0.64 \\
$\mathrm{ThO}_{2}$ & 1.33 & 0.07 & 0.30 & 0.44 & 0.49 & 0.04 & 0.69 & 0.89 & 1.00 & 0.18 \\
$\mathrm{UO}_{2}$ & 4.23 & 4.03 & 1.96 & 2.55 & 3.47 & 0.81 & 3.66 & 0.19 & 1.97 & 1.22 \\
$\mathrm{H}_{2} \mathrm{O}$ & 0.87 & 0.74 & 1.51 & 1.49 & 0.15 & 0.82 & 1.67 & 0.10 & 0.33 & 0.49 \\
\hline Total & 97.78 & 98.22 & 100.51 & 96.16 & 87.81 & 96.81 & 93.32 & 88.85 & 90.82 & 93.33 \\
\hline
\end{tabular}

Cation and $\mathrm{OH}$ per cent

\begin{tabular}{|c|c|c|c|c|c|c|c|c|c|c|}
\hline $\mathrm{Si}$ & 43.20 & 44.01 & 40.29 & 40.71 & 48.91 & 44.31 & 39.59 & 44.20 & 47.47 & 46.92 \\
\hline $\mathrm{Zr}+\mathrm{Hf}$ & 43.00 & 44.36 & 43.25 & 43.41 & 46.85 & 45.52 & 44.11 & 43.95 & 47.28 & 48.89 \\
\hline $\mathrm{Fe}$ & 0.31 & 0.06 & 0.76 & 1.57 & 0.35 & 1.60 & 0.71 & 0.14 & 0.09 & 0.03 \\
\hline $\mathrm{Ca}$ & 2.31 & 0.11 & 2.97 & 1.52 & 0.27 & 1.44 & 1.61 & 2.09 & 1.34 & 0.34 \\
\hline $\mathrm{P}$ & 2.45 & 2.04 & 2.22 & 1.55 & 0.16 & 1.39 & 1.22 & 5.18 & 0.50 & nil \\
\hline$Y$ & 1.92 & 2.21 & 1.41 & 2.46 & 0.44 & 0.81 & 1.55 & 3.37 & nil & nil \\
\hline $\mathrm{Ln}$ & 0.49 & 1.80 & 0.87 & - & 0.47 & 0.32 & 0.42 & - & 0.08 & 0.37 \\
\hline Th & 0.47 & 0.03 & 0.98 & 0.16 & 0.21 & 0.02 & 0.26 & 0.37 & 0.42 & 0.07 \\
\hline $\mathrm{U}$ & 1.49 & 1.44 & 0.65 & 0.88 & 1.41 & 0.28 & 1.35 & 0.08 & 0.80 & 0.48 \\
\hline $\mathrm{OH}$ & 4.56 & 3.96 & 7.49 & 7.74 & 0.93 & 4.31 & 9.19 & 0.62 & 2.03 & 2.88 \\
\hline
\end{tabular}

Atomic proportions of lanthanoides based on $\mathrm{La}+\cdots \mathrm{Lu}=100$.

\begin{tabular}{|c|c|c|c|c|c|c|c|c|c|c|}
\hline $\mathrm{La}$ & nil & nil & nil & $* *$ & 6.6 & nil & nil & $* *$ & 4.4 & 36.2 \\
\hline $\mathrm{Ce}$ & 2.3 & nil & nil & & 11.6 & nil & nil & & 4.5 & 5.2 \\
\hline $\operatorname{Pr}$ & 0.6 & nil & 1.9 & & 6.0 & 4.1 & 4.8 & & 15.1 & nil \\
\hline $\mathrm{Nd}$ & nil & nil & nil & & 1.4 & 2.3 & nil & & nil & 3.1 \\
\hline $\mathrm{Sm}$ & 0.2 & nil & 0.1 & & nil & 0.3 & nil & & nil & 0.1 \\
\hline $\mathrm{Eu}$ & nil & nil & 1.4 & & 6.5 & nil & nil & & nil & nil \\
\hline $\mathrm{Gd}$ & 4.0 & 1.1 & 3.5 & & 23.9 & 44.0 & 21.4 & & nil & 6.5 \\
\hline $\mathrm{Tb}$ & 0.8 & 2.7 & 4.3 & & nil & 10.3 & nil & & 11.0 & 1.3 \\
\hline Dy & 33.6 & 7.0 & 7.3 & & 22.7 & 17.8 & 54.8 & & 2.6 & 24.3 \\
\hline Ho & 3.7 & 42.3 & nil & & nil & nil & nil & & nil & nil \\
\hline Er & 20.4 & 16.1 & 15.2 & & 11.9 & 14.6 & 14.3 & & 40.5 & 23.2 \\
\hline $\mathrm{Tm}$ & 13.1 & 3.2 & 2.6 & & 7.0 & 6.0 & nil & & 10.0 & nil \\
\hline $\mathrm{Yb}$ & 19.4 & 23.7 & 51.8 & & 2.5 & 0.5 & 4.8 & & 11.9 & nil \\
\hline $\mathrm{Lu}$ & nil & 3.8 & 12.0 & & nil & nil & nil & & nil & nil \\
\hline
\end{tabular}

$*=$ total $\mathrm{Fe}$ as $\mathrm{FeO}, * *=$ not determined, n.d. = not detected, water calculated as charge balance.

zircon samples (Törnroos 1984), this was the method used in the present study. The results are given in Table 1 . The table also compares the corresponding calculated $\mathrm{wt}_{\%} \mathrm{\textrm {P } _ { 2 }} \mathrm{O}_{5}$ and the chemically analysed $\mathrm{wt} \% \mathrm{P}_{2} \mathrm{O}_{5}$, revealing a considerable difference in the values of speci- mens 4 (2), 13 (8) and 16 (9). These specimens (numbers in brackets) are the three that deviate from the line RE : P = $1: 1$ (Fig. 2 of Törnroos 1982). This indicates that the excess of phosphorus in specimens (2) and (8) is not incorporated in xenotime. The phosphorus con- 
tent of specimen (9) on the other hand seems to have been determined as too low.

\section{Investigations with electron probe instrument (EPI)}

The analyses were performed by the author with a JEOL JCXA-733 microprobe. The accelerating voltage was $15 \mathrm{kV}$ and the probe current $15 \mathrm{nA}$. Cubic zirconia was used as the standard for $\mathrm{Zr}, \mathrm{Y}$ and $\mathrm{Hf}$, natural minerals for Si, $\mathrm{Fe}, \mathrm{Ca}, \mathrm{P}, \mathrm{La}, \mathrm{Ce}, \mathrm{Pr}, \mathrm{Nd}$ and $\mathrm{Th}$, synthetic glass for $\mathrm{U}$, and pure metals for the other REEs. Energy dispersive spectrometry (EDS) was employed for the qualitative determinations.

Backscattered electron images (BEI) are useful in studies of compositional differences in a specimen, permitting one to see domains of relatively high and low density as small as $1 \mu \mathrm{m}$ in size, provided that the mass contrasts are of sufficient magnitude to produce different shades of grey.

The new microprobe analyses of the zircon samples given in Table 2 reveal that both uranium and thorium are present in appreciable amounts! In the completely metamict parts of the samples these elements show values of $1-3$ wt \% ( $c f$. Figs. 2 and 6). Rare earths and phosphorus occur sparsely in the non-metamict zircon phase but are more abundant in the metamict parts (see Table 4). Several analyses on the epitaxially intergrown xenotime, however, reveal appreciable amounts of lanthanoids and thorium, but only small amounts of uranium. Three analyses on intergrown xenotime are given in Table 3. These analyses correspond to Oleg v. Knorring's analysis of xenotime from the Morrua pegmatite, Mozambique (Sahama et al. 1973), especially in the high lanthanoide concentrations. The atomic ratio of yttrium to the sum of lanthanoides is $78: 22$ in Morrua and $79-84: 21-16$ in the intergrown xenotime (see Table 3 ).
Figure 1 shows an autoradiograph of zircon specimen LM 4541 from Zambézia. The white areas display domains with high uranium and thorium contents (alpha emitters). A closer

Table 3. Microprobe analyses of intergrown xenotime from the Zambézia zircon specimens.

\begin{tabular}{|c|c|c|c|}
\hline & 1 & 2 & 3 \\
\hline $\mathrm{SiO}_{2}$ & 2.67 & 4.08 & 0.80 \\
\hline $\mathrm{ZrO}_{2}$ & 1.37 & 5.21 & n.d. \\
\hline $\mathrm{HfO}_{2}$ & n.d. & n.d. & ** \\
\hline $\mathrm{FeO}^{*}$ & 0.24 & 0.52 & ** \\
\hline $\mathrm{CaO}$ & 0.32 & 0.28 & 0.04 \\
\hline $\mathrm{P}_{2} \mathrm{O}_{5}$ & 33.4 & 32.5 & 34.4 \\
\hline $\mathrm{Y}_{2} \mathrm{O}_{3}$ & 42.5 & 41.0 & 44.7 \\
\hline $\mathrm{Ln}_{2} \mathrm{O}_{3}$ & 18.0 & 15.2 & 14.6 \\
\hline $\mathrm{ThO}_{2}$ & 1.11 & 1.08 & 1.43 \\
\hline $\mathrm{UO}_{2}$ & 0.40 & 0.52 & 1.00 \\
\hline Total & 100.81 & 100.39 & 96.97 \\
\hline \multicolumn{4}{|c|}{ Cation per cent } \\
\hline $\mathrm{Si}$ & 4.37 & 6.60 & 1.16 \\
\hline $\mathrm{Zr}+\mathrm{Hf}$ & 1.10 & 4.10 & nil \\
\hline $\mathrm{Fe}$ & 0.33 & 0.70 & - \\
\hline $\mathrm{Ca}$ & 0.56 & 0.50 & 0.07 \\
\hline $\mathrm{P}$ & 46.28 & 44.52 & 49.42 \\
\hline $\mathrm{Y}$ & 37.01 & 35.30 & 40.35 \\
\hline Ln & 9.80 & 7.69 & 7.87 \\
\hline Th & 0.41 & 0.40 & 0.55 \\
\hline $\mathrm{U}$ & 0.15 & 0.18 & 0.38 \\
\hline
\end{tabular}

Atomic proportions of lanthanoides based on $\mathrm{La}+\cdots \mathrm{Lu}=$ 100.

\begin{tabular}{|c|c|c|c|}
\hline $\mathrm{La}$ & 0.6 & 1.4 & nil \\
\hline $\mathrm{Ce}$ & 0.3 & 0.5 & 0.4 \\
\hline $\operatorname{Pr}$ & nil & nil & 2.2 \\
\hline $\mathrm{Nd}$ & nil & nil & 0.2 \\
\hline $\mathrm{Sm}$ & 0.01 & nil & 0.01 \\
\hline $\mathrm{Eu}$ & nil & nil & nil \\
\hline Gd & 12.2 & 7.7 & 12.0 \\
\hline $\mathrm{Tb}$ & 4.5 & nil & 2.2 \\
\hline Dy & 28.8 & 16.7 & 21.2 \\
\hline Ho & nil & nil & nil \\
\hline Er & 20.6 & 23.3 & 23.8 \\
\hline Tm & 2.4 & 2.3 & 2.9 \\
\hline $\mathrm{Yb}$ & 27.0 & 44.2 & 27.6 \\
\hline $\mathrm{Lu}$ & 3.5 & 4.0 & 1.4 \\
\hline Y : Ln & $79: 21$ & $82: 18$ & $84: 16$ \\
\hline
\end{tabular}




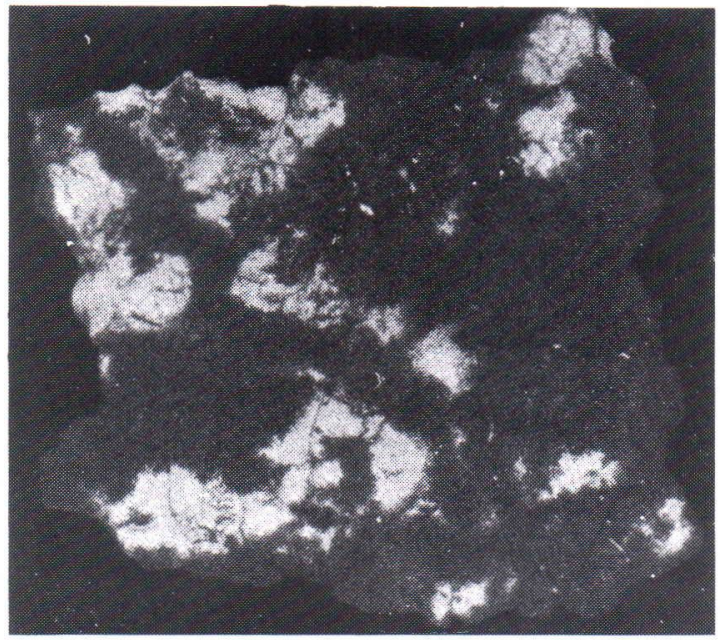

Fig. 1. Autoradiograph of zircon specimen N:r LM 4541. Specimen size $1.5 \times 1.5 \mathrm{~cm}$.

study of such an area (Fig. 2) reveals three facts: 1) Uranium and thorium are concentrated in their own phases throughout the area (white spots in Figs. 2 B and C), with 2) embedded completely metamict parts (black areas in Fig. 2 A) with evenly distributed uranium and thorium (Fig. 2 C). 3) Three types of zircon occur: a) completely metamict (cf. Fig. 2 D), b) almost non-metamict (Fig. 2 E), and c) partly metamict (Fig. 2 F). Corresponding analyses are given in Table 4.

The white spots are closely spaced within the domains but more scattered throughout the rest of the specimen. As seen from Figure $2 \mathrm{G}$, these spots constitute uranium and thorium compounds. The ratio $\mathrm{U}$ : Th may vary greatly, however, and almost pure thorium phases also occur. Sparse galena spots are encountered too (cf. Köppel \& Sommerauer 1974, p. 72).
Table 4. Microprobe analyses of zircon No. 2. Specimen LM 4541.

\begin{tabular}{lccc}
\hline & 1 & 2 & 3 \\
\hline $\mathrm{SiO}_{2}$ & 30.1 & 31.2 & 31.3 \\
$\mathrm{ZrO}_{2}$ & 54.1 & 58.5 & 61.5 \\
$\mathrm{HfO}_{2}$ & 3.12 & 3.34 & 3.44 \\
$\mathrm{Al}_{2} \mathrm{O}_{3}$ & 0.76 & 0.68 & n.d. \\
$\mathrm{FeO}^{*}$ & 0.95 & 1.05 & 0.11 \\
$\mathrm{CaO}$ & 2.18 & 0.63 & 0.78 \\
$\mathrm{P}_{2} \mathrm{O}_{5}$ & 0.11 & 0.10 & 0.11 \\
$\mathrm{Y}_{2} \mathrm{O}_{3}$ & 1.54 & 0.91 & 0.46 \\
$\mathrm{Ln}_{2} \mathrm{O}_{3}$ & 2.18 & $* *$ & 0.58 \\
$\mathrm{ThO}_{2}$ & 1.72 & 1.13 & 0.67 \\
$\mathrm{UO}_{2}$ & 2.15 & 0.99 & 0.20 \\
$\mathrm{H}_{2} \mathrm{O}$ & 0.90 & 0.46 & 0.34 \\
\hline $\mathrm{Total}$ & 99.81 & 98.99 & 96.05 \\
\hline
\end{tabular}

Cation and $\mathrm{OH}$ per cent

\begin{tabular}{lrrr}
\hline $\mathrm{Si}$ & 45.01 & 47.55 & 48.12 \\
$\mathrm{Zr}+\mathrm{Hf}$ & 40.78 & 44.93 & 47.61 \\
$\mathrm{Al}$ & 1.34 & 1.22 & nil \\
$\mathrm{Fe}$ & 1.19 & 1.34 & 0.14 \\
$\mathrm{Ca}$ & 3.49 & 1.03 & 1.28 \\
$\mathrm{P}$ & 0.14 & 0.13 & 0.14 \\
$\mathrm{Y}$ & 1.23 & 0.74 & 0.38 \\
$\mathrm{Ln}$ & 1.01 & - & 0.28 \\
$\mathrm{Th}$ & 0.58 & 0.39 & 0.23 \\
$\mathrm{U}$ & 0.72 & 0.34 & 0.07 \\
$\mathrm{OH}$ & 4.51 & 2.35 & 1.74 \\
\hline
\end{tabular}

Atomic proportions of lanthanoides based on $\mathrm{La}+\cdots \mathrm{Lu}=$ 100 .

\begin{tabular}{lrrr}
\hline $\mathrm{Ce}$ & 3.2 & $* *$ & nil \\
$\mathrm{Pr}$ & 2.7 & & 3.0 \\
$\mathrm{Nd}$ & 0.3 & & nil \\
$\mathrm{Sm}$ & 0.1 & nil \\
$\mathrm{Eu}$ & nil & 10.5 \\
$\mathrm{Gd}$ & 0.6 & nil \\
$\mathrm{Tb}$ & 2.4 & nil \\
$\mathrm{Dy}$ & 8.4 & 7.9 \\
$\mathrm{Er}$ & 13.4 & 10.7 \\
$\mathrm{Tm}$ & 5.8 & 13.2 \\
$\mathrm{Yb}$ & 50.7 & 43.6 \\
$\mathrm{Lu}$ & 12.7 & 10.9 \\
\hline
\end{tabular}

$*$ = total $\mathrm{Fe}$ as $\mathrm{FeO}, * *=$ not determined, n.d. $=$ not detected, water calculated as charge balance. Analyses correspond to the areas in Fig. 2: 1) totally metamict, 2) zircon closely intergrown with uraninite-thorianite specks, 3) almost nonmetamict zircon.

Fig. 2. Zircon specimen LM 4541, A) photomicrograph of domain part. B) Backscattered electron image (BEI) of the same part as in A). Length of bar $=100 \mu \mathrm{m}$. C) Enlargement of completely metamict part with evenly distributed uranium and thorium. Length of bar $=100 \mu \mathrm{m}$. D) ED spectrum of completely metamict zircon. E) ED spectrum of almost nonmetamict zircon. F) ED spectrum of partly metamict zircon in the domain. G) ED spectrum of a U-rich inlusion. 
Metamict zircon from Mozambique 187

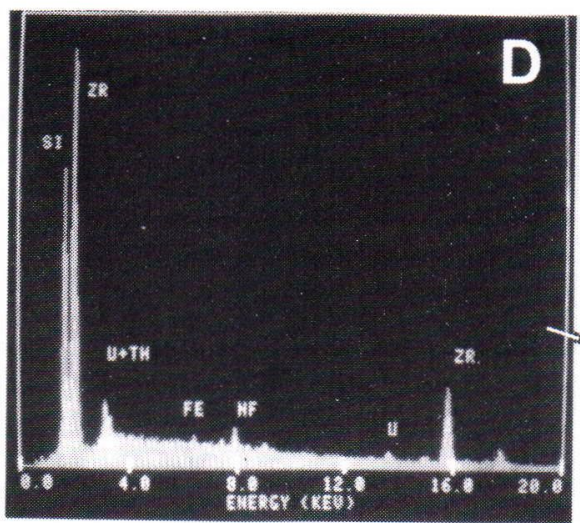

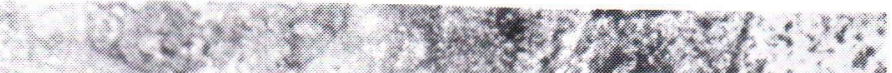

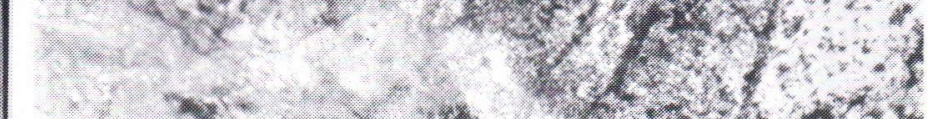

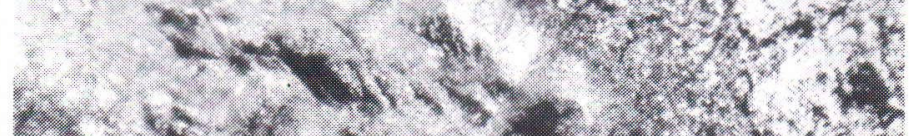

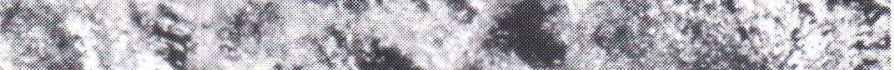

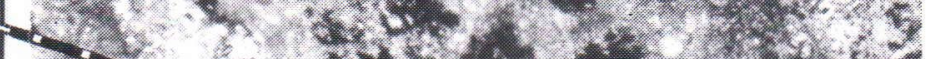

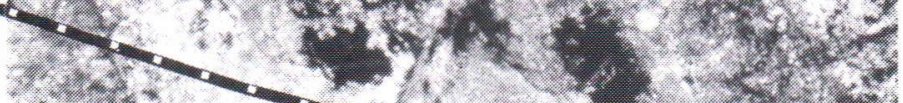

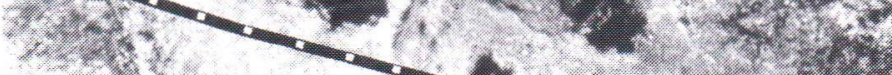
-

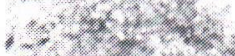

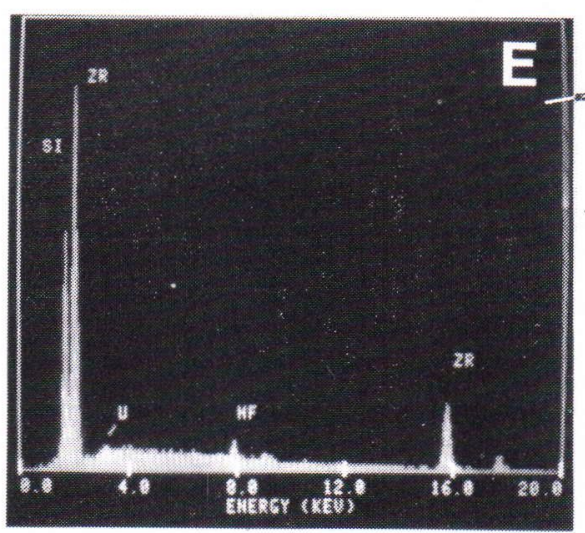

atcin -3
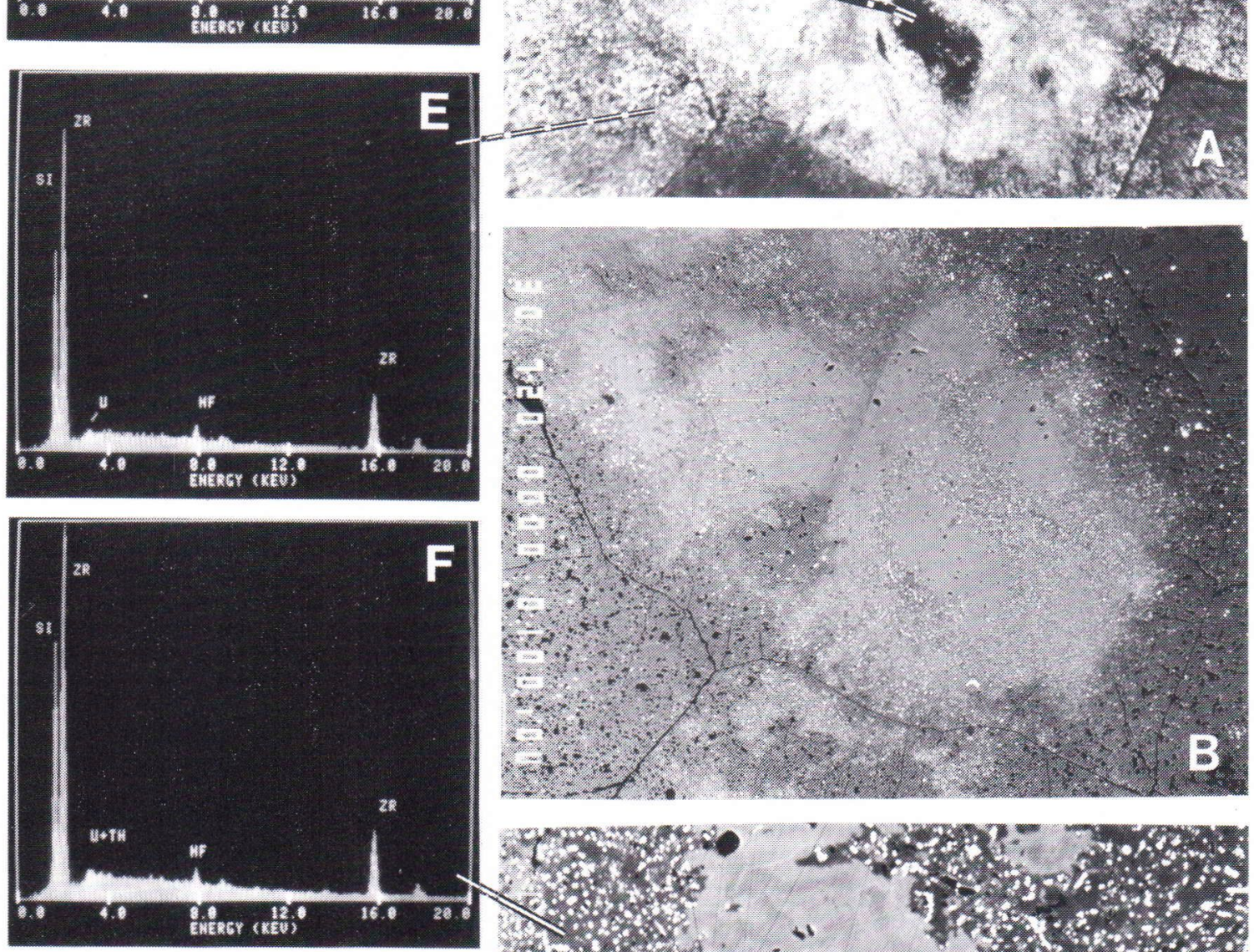

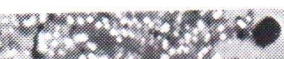

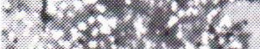
cos.

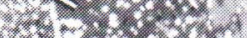

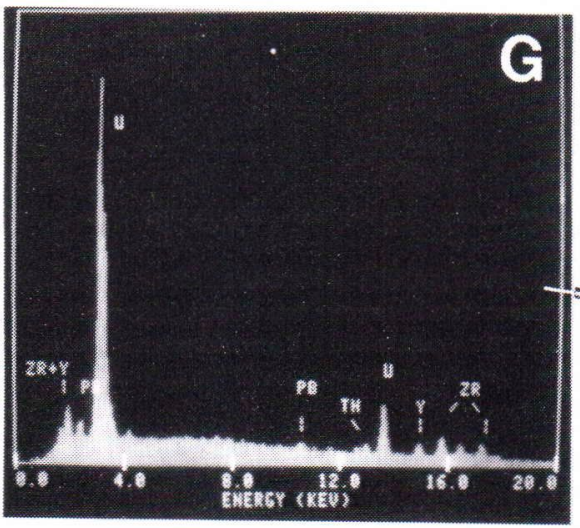

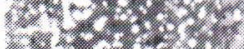

sor.t.

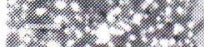

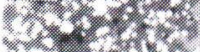

wet:

$=\cos 2$.

nis.

$-3.60 .2=$

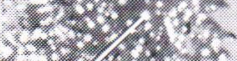

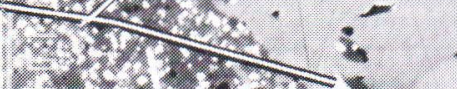

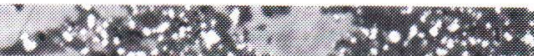

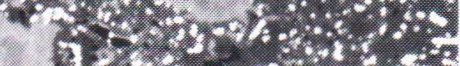

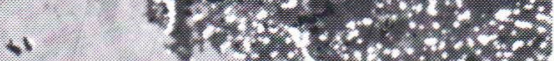

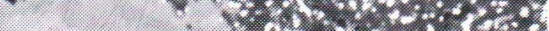

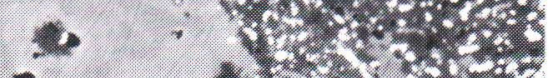

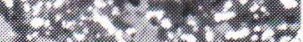

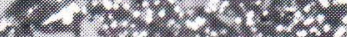
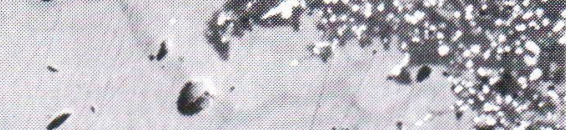

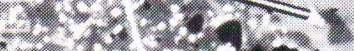
$-7.6 \times 1$. - 6.62

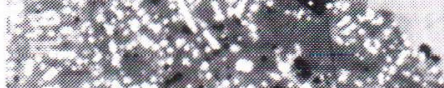




\section{X-ray diffraction}

The X-ray powder diffraction patterns were recorded with a Philips wide angle goniometer with a Wallac single channel analyser using Nifiltered $\mathrm{CuK}$ radiation. The internal standard was a pure spinel from Ceylon ( $\mathrm{a}=8.088 \AA$ ). The diffraction patterns were recorded in the range of $2 \theta=18^{\circ}-70^{\circ}(1 / 2$ degree of $2 \theta$ per minute) with the setting $20 \mathrm{~mA} / 35 \mathrm{kV}$.

\section{Infrared spectroscopy}

X-ray diffraction gives information on the long range ordering in a crystal lattice; it gives poor or no information on metamict minerals, with a destroyed lattice. IR spectroscopy on the other hand gives information on the short range ordering in the lattice and is therefore especially useful in studies of metamict minerals.

Zircon belongs to the space group $\mathrm{D}_{4 \mathrm{~h}}^{19}-\mathrm{I} 41 /$ amd, a structure in which the anions occupy $\mathrm{D}_{2 \mathrm{~d}}$ sites. According to Hezel and Ross (1966), there are only four IR-active vibration forms in such a structure: two valence vibrations $\left(\nu_{3}\right)$ and two deformation vibrations $\left(\nu_{4}\right)$. The interaction between anion and cation in the zircon structure is rarely seen by IR spectroscopy $(\mathrm{Hu}-$ bin \& Tarte 1971).

Xenotime and Dy-Lu phosphates have the same structure as zircon and therefore also the same vibration forms. The vibration bands in the IR spectra of zircon and the Dy-Lu phos-

Table 5. The wave lengths of infrared active vibration bands of zircon and xenotime. Compiled after Dawson et al. (1971) and Hezel \& Ross (1966).

\begin{tabular}{lccc}
\hline $\begin{array}{l}\text { Zircon } \\
(\mu \mathrm{m})\end{array}$ & Vibration form & $\begin{array}{c}\text { Xenotime } \\
(\mu \mathrm{m})\end{array}$ \\
\hline 10.0 & $\nu_{3}$ & valence vibration & 9.5 \\
11.1 & & & 10.1 \\
16.2 & $\nu_{4}$ & deformation vibration & 15.6 \\
23.0 & & & 19.2 \\
\hline
\end{tabular}

phates are due to the vibrations caused by the $\mathrm{SiO}_{4}$ tetrahedron and $\mathrm{PO}_{4}$ thetrahedron, respectively. Table 5 gives the wave lengths for these vibration bands of zircon and xenotime.

The deformation vibration band at $16.2 \mu \mathrm{m}$ is the only one that is free from overlapping of adjacent bands. Because it is due to the vibrations within the $\mathrm{SiO}_{4}$ tetrahedron, it is practically insensitive to small amounts of cation substitution. It can therefore be used as a measure of the degree of metamictisation in zircon (Hubin \& Tarte 1971, Deliens et al. 1977).

The IR spectra were obtained using the $\mathrm{KBr}$ pressed pellet technique. It was necessary to mix $6.00 \mathrm{mg}$ of the powdered metamict samples instead of the normal $3 \mathrm{mg}$ in $1000 \mathrm{mg}$ of $\mathrm{KBr}$ to obtain sufficiently »intense» absorption bands. The spectra were recorded with a Leitz double beam infrared spectrophotometer with both $\mathrm{NaCl}$ and $\mathrm{KBr}$ prisms. The wave length range is thus from $1 \mu \mathrm{m}$ to $24 \mu \mathrm{m}$. In the wave length range $1-5 \mu \mathrm{m}$ only adsorbed water is active and is not shown in Figure 4. Figure 4, spectrum A shows a typical IR spectrum of a metamict zircon; only weak and diffuse absorption bands are present. The weak bands at 15.6 $\mu \mathrm{m}$ and $19.2 \mu \mathrm{m}$ are from xenotime ( $c f$. Fig. 4, spectrum $\mathrm{X}$ ).

\section{DT and TG analysis}

Zircon is normally considered to be thermally inactive. Metamict zircon sometimes glows when heated (Henneberg 1846), indicating that the material emits energy at a certain stage. This energy can be recorded by DTA, as demonstrated by Kulp et al. (1952) and Sommerauer (1976).

The DTA and TGA runs performed on the Zambézia material were obtained using a Rigacu Denki Thermoflex DTA and TGA apparatus. 15-20 $\mathrm{mg}$ of the powdered specimens were weighed out in small Pt-mugs. The same amount of $\mathrm{Al}_{2} \mathrm{O}_{3}$ was used as reference. The preparations were run in $\mathrm{Ar}$ atmosphere up to $1100^{\circ} \mathrm{C}$ with $\Delta \mathrm{T}=10^{\circ} \mathrm{C} / \mathrm{min}$. 
A weak exothermic reaction occurs in the range $860^{\circ} \mathrm{C}-940^{\circ} \mathrm{C}$. The TG curves show a weight loss in the temperature range $100^{\circ}-$ $1000^{\circ} \mathrm{C}$. No endothermic reactions are observed.

\section{Annealing treatment}

Metamict zircon is known to »recrystallise» when heated. A series of experiments was conducted to study the course of recrystallisation.
The preparations were heated at different temperatures and then studied by X-ray diffraction and IR spectroscopy.

The most important physical changes produced on heating the metamict zircon samples from Mozambique are given in Table 6. As expected, the X-ray diffraction lines grow in number and intensity and are also sharper (Fig. 3). For almost completely metamict zircon a sharp pattern is not obtained, even after prolonged heating (several days at $1150^{\circ} \mathrm{C}$ ). X-ray diffraction patterns of such specimens already show

Table 6. Physical changes in heated metamict zircon from Zambézia, Mozambique.

\begin{tabular}{|c|c|c|c|}
\hline $\mathrm{T}$ & $\mathrm{X}$-ray diffraction & IR spectroscopy & Fig. 3-4 \\
\hline room & weak principal lines (200), (112) & $\begin{array}{l}\text { weak trace of vibr. bands } \\
\text { at } 16.2 \mu \mathrm{m}\end{array}$ & A \\
\hline $500^{\circ} \mathrm{C}$ & slightly sharper principal lines. & $-»-$ & \\
\hline $710^{\circ} \mathrm{C}$ & $\begin{array}{l}\text { slightly improved recrystallisation, traces } \\
\text { of additional diffraction lines. }\end{array}$ & $-»-$ & \\
\hline $850^{\circ} \mathrm{C}$ & $\begin{array}{l}\text { further improved recrystallisation, } \\
\mathrm{ZrO}_{2} \text { phase appears. }\end{array}$ & $\begin{array}{l}\text { distinct vibration bands } \\
\text { at } 16.2 \text { and } 22-23 \mu \mathrm{m} \text {. }\end{array}$ & B \\
\hline $1060^{\circ} \mathrm{C}$ & $\begin{array}{l}\text { recrystallised, sharp diffr. lines, } \\
\text { still } \mathrm{ZrO}_{2} \text { phase. }\end{array}$ & $\begin{array}{l}\text { sharply marked vibration bands } \\
\text { at } 16.2,22.1 \text { and } 23.1 \mu \mathrm{m} \text {. }\end{array}$ & $\mathrm{C}$ \\
\hline $1150^{\circ} \mathrm{C}$ & sharp lines, $\mathrm{ZrO}_{2}$ phase decreases. & sharp vibration bands. & \\
\hline
\end{tabular}

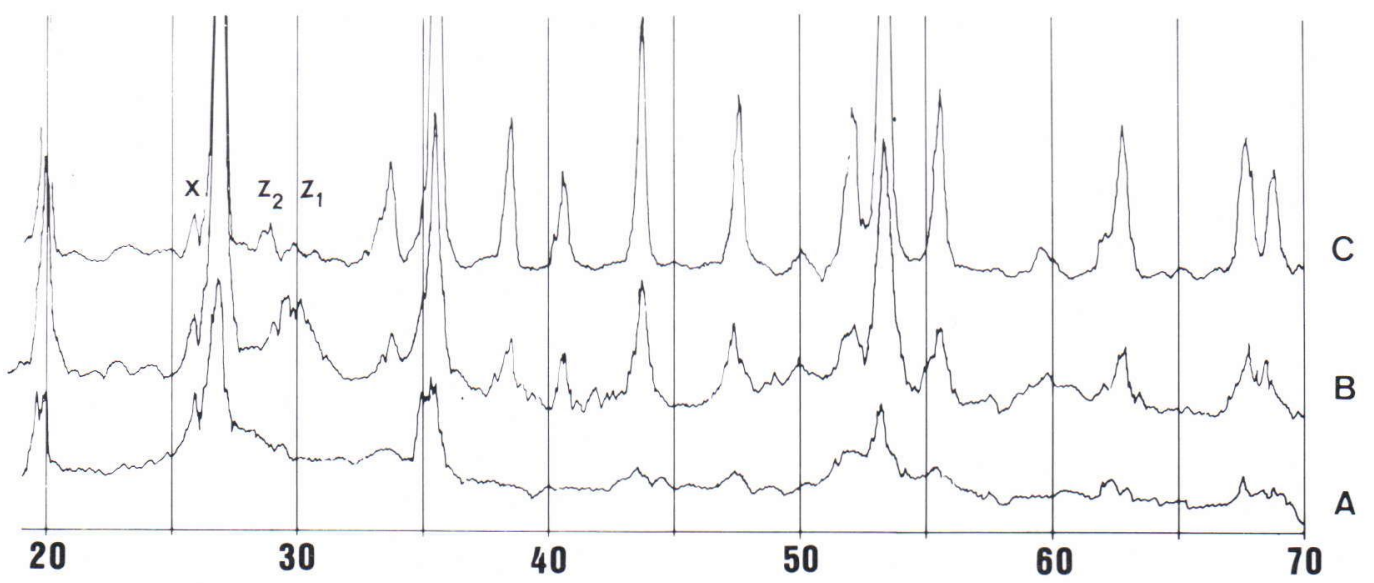

degree 20

Fig. 3. X-ray diffraction patterns for A) metamict zircon, B) after heating for 24 hours at $850^{\circ} \mathrm{C}$. C) at $1060^{\circ} \mathrm{C}$. $\mathrm{X}=$ xenotime (200)-line and $\mathrm{Z}_{1}$ and $\mathrm{Z}_{2}=\mathrm{ZrO}_{2}$ phases, tetragonal and monoclinic modification respectively. 


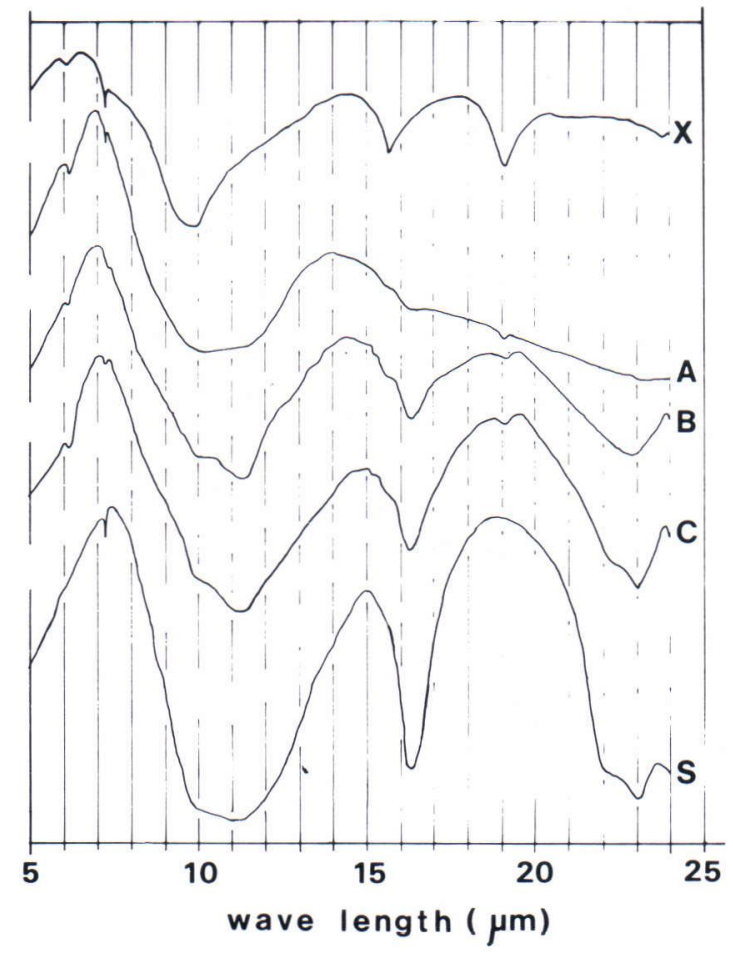

Fig. 4. Infrared spectra of the same preparations as in Fig. 3. A) unheated, B) heated for 24 hours at $850^{\circ} \mathrm{C}, \mathrm{C}$ ) $1060^{\circ} \mathrm{C} . \mathrm{X}=$ xenotime from Mozambique and $\mathrm{S}=$ nonmetamict zircon from Siilinjärvi, Finland.

the lines of zirconium dioxide at temperature of $850^{\circ} \mathrm{C}$.

The values of cell parametres decrease and approach those for natural non-metamict zircon, that is, $\mathrm{a}=6.608 \AA$ and $\mathrm{c}=6.008 \AA$. In accordance with this the cell volume decreases to $262 \AA^{3}$ (Törnroos 1982).

With increasing temperature the IR absorption bands are enhanced in the range $7 \mu \mathrm{m}$ to 15 $\mu \mathrm{m}$. New bands appear in the range $15 \mu \mathrm{m}$ to 24 $\mu \mathrm{m}$. Because only the vibrations from the $\mathrm{SiO}_{4}$ tetrahedrons are IR active, their number is obviously growing, i.e. recrystallisation occurs.

In Figure 4 (spectra B and C) are shown IR spectra of heated metamict zircon. The spectrum $\mathrm{S}$ in the figure represents non-metamict zircon from Siilinjärvi, Finland.

\section{Discussion}

The idiomorphic to hypidiomorphic habit of the metamict Zambézia zircon crystals implies that the mineral originally crystallised with a higher degree of order. Sommerauer (1976) shows that metamict zircon comprises two phases, $Z_{K}$ and $Z_{M}$, of which the $Z_{K}$ phase is an extraordinarily stable system and the $Z_{M}$ phase a very instable one. Where $Z_{K}$ phases are connected with $\mathrm{Z}_{\mathrm{M}}$ phases always a polycrystalline domain structure of randomly oriented crystallites builds up, giving a diffuse X-ray diffraction pattern.

Figure 3, tracing $\mathrm{B}$ shows that a $\mathrm{ZrO}_{2}$ phase appears by heating metamict zircon. This confirms the occurrence of amorphous or perhaps gel-like $\mathrm{ZrO}_{2}$ in the metamict zircon.

It is well known that metamictisation is caused or, at least facilitated by the effect of nuclear radiation from the decay of $U$ and $T h$ and their daughter elements (for references see e.g. Sommerauer 1976). Autoradiographical studies of the Zambézia zircon samples reveal that radioactive elements (alpha emitters) are clustered in domains randomly distributed in the samples. With an electron probe instrument it is shown that only part of the uranium and thorium present is evenly distributed in the zircon (Fig. 2); usually these elements build up their own phases (probably uraninite-thorianite) disseminated in the domains (Fig. 2) or occuring as crack fillings in the zircon crystals or between crystal grains (Fig. 5); thorium in particular occurs in the intergrown xenotime.

In spite of relative resistance to weathering, zircon can alter in an oxidising environment such as in the presence of gummite or thorogummite, and release small quantities of zirconium and of other elements building up the thorium-uranium-zirconium phases found in the fractures (Rimsaite 1981).

Why the earlier microprobe determinations failed to detect the uranium and thorium is beyond the author's judgment. The low contents 
Fig. 5. BEI of thorium-rich crack filling in zircon LM 5189. Length of bar $=100 \mu \mathrm{m}$.

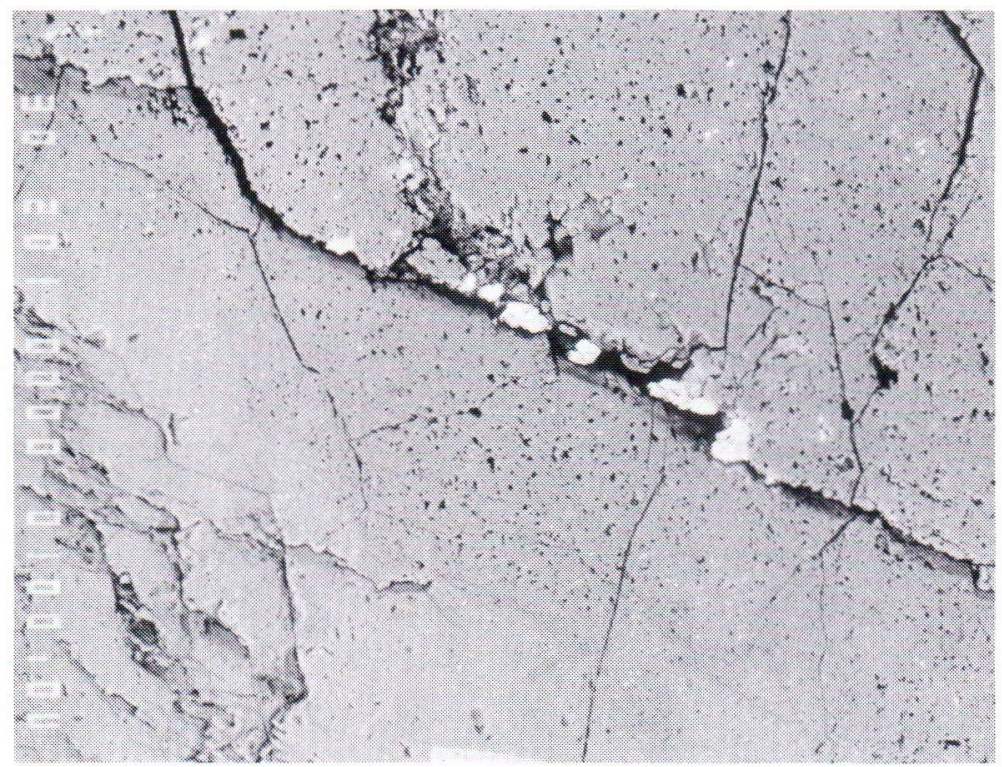

reported in the wet-chemical analyses, on the other hand, are easier to explain. The mode of occurrence (own phases of very small grains) implies that most of these elements are loosely bound in the zircon samples. This is supported by investigations by Sansoni (1966). He also shows experimentally that uranium may easily be diluted by water from zircon samples.

During the sample treatment the material was ground down to $1-3 \mu \mathrm{m}$ particle size. The material was washed in water or alcohol several times. Thorium and especially uranium are accordingly easily removed from the specimens.

Caruba et al. (1975) have experimentally shown that uranium, but not thorium can substitute for zirconium in the zircon lattice. This is illustrated in the analyses in Tables 2 and 3. Very little thorium is present in the zircon analyses compared with uranium, whereas thorium may by present in highly appreciable amounts in the inclusions or crack fillings or in the epitaxially intergrown xenotime.

Uranium and thorium are enriched in the domains as disseminated spots. Considerable amounts of these elements $(1-3 \mathrm{wt} \%)$ are even- ly distributed only in the glassy (completely metamict) parts of the zircon; elsewhere in the sample only about $0.4 \mathrm{wt} \%$ are encountered.

Although zonal growth occurs in the Zambézia samples, the uranium and thorium domains only appear in the central part of the zircon grains. The samples from Zambézia consist of crystal aggregates, and the domains thus appears to be randomly distributed. The domains and the totally metamict parts show some degree of idiomorphism. It is therefore implied that during the history of growth, the uranium (and thorium) contents of the crystallising fluids were in the beginning of such an order that they could be incorporated in the zircon lattice, then the contents of the radioactive elements in the fluids grew drastically and own uranium and thorium phases intergrew in the growing zircon crystal surrounding the first small crystal germs. Finally the uranium and thorium contents were lowered until about the $0.4 \mathrm{wt} \% \mathrm{U}$ and $0.2 \mathrm{wt} \% \mathrm{Th}$ mentioned were evenly distributed in the zircon.

Dissemination of such thorium and uranium phases has recently been described by Rimsaite 

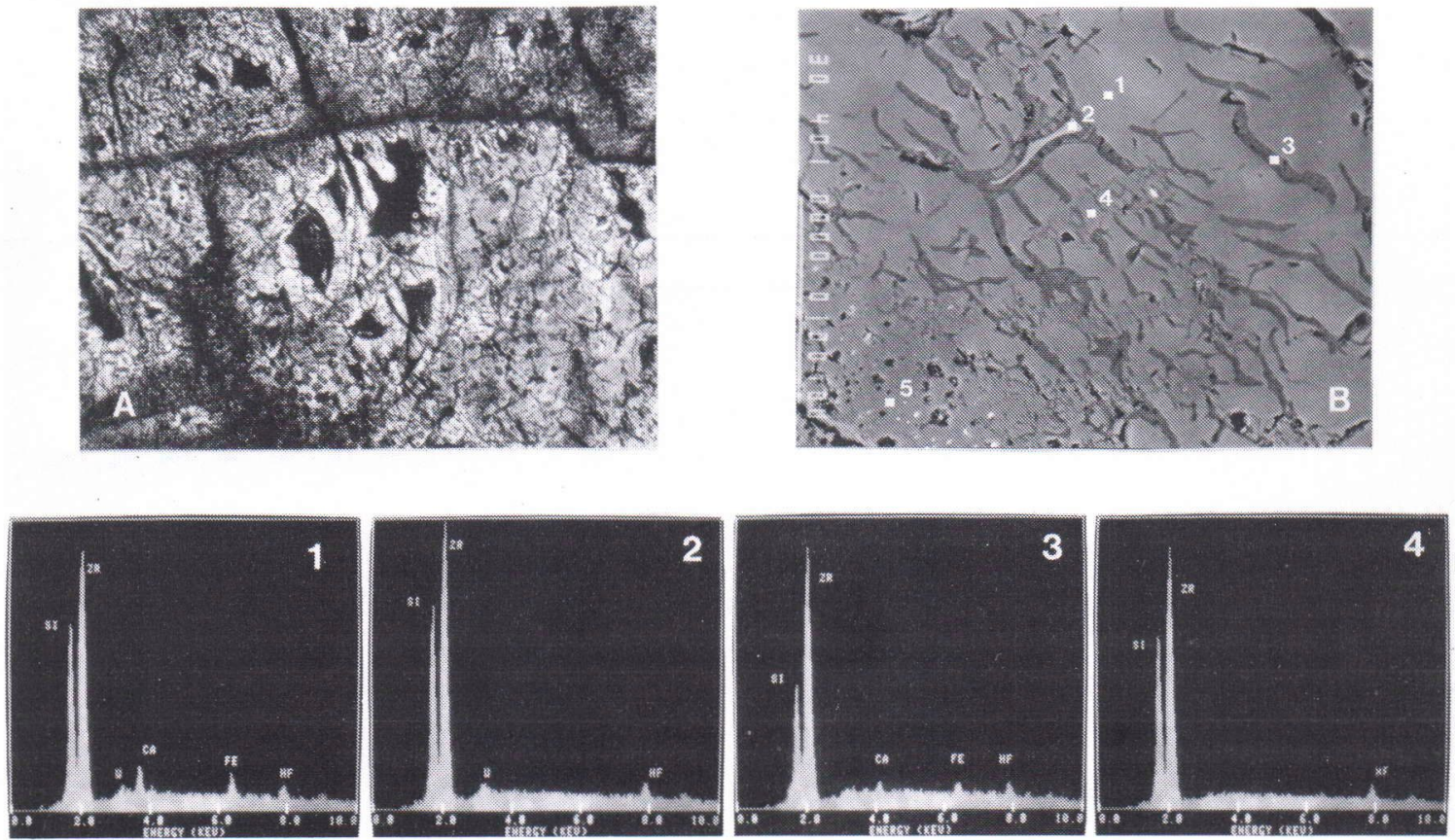

Fig. 6. Zircon specimen LM 4368, A) photomicrograph of a glassy part with completely metamict area (black), crossed nic. $25 \times$. B) BEI of the glassy part $(400 \times)$, showing five different phases: 1) main glassy phase, 2) completely metamict part, 3) dessication crack filling, 4) phase cutting the dessication cracks and the main glassy phase, 5) the more crystallised zircon part surrounding the glassy gel-like areas. Length of bar $=100 \mu \mathrm{m} .1-4)$ ED spectra of the corresponding phases in B.

(1981) from shattered cores of highly zoned zircon crystals from radioactive granites in the Greenville Structural Province of Quebec and Ontario. According to him, the zonal crystals consist of a core and alternating anisotropic and isotropic growth zones. The cores consist of a group of small idiomorphic zircon crystals, fragments of shattered zircon, uraninite and uranothorite grains. He interprets the spots and fragments of uraninite, uranothorite, apatite, galena and felspar encountered as coeval with the hosting zircon zones or assigns their formation to the end of a cycle of episodic zircon growth, which means that they are close in age to both adjacent growth zones. After some interruption new overgrowth zones form and many crystals provide evidence of several interrupted episodes of growth.

The glassy part of some samples of the Zam- bézia material contains considerable amounts of $\mathrm{Ca}$ and $\mathrm{Fe}$ (analysis 1 in Table 7). Except for $\mathrm{Al}$, the composition is reminiscent of the naegite described by Lipova and Shumkova (1973), whereas in appearance they look like the gel-like malcon described by Turovskij et al. (1966). A glassy part is shown in Figure 6. Figure $6 \mathrm{~A}$ is a thin-section photomicrograph (specimen LM 4368) showing a part with completely metamict (black) zircon surrounded by a glassy gel-like mass appearing slightly anisotropic (light grey).

The BEI (Fig. $6 \mathrm{~B}$ ) reveals that at least five phases corresponding to the analyses given in Table 7 occur in the glass gel: It contains cracks resembling dessication cracks filled with a material (Fig. 6, ED spectrum 3, anal. 3 in Table 7) leached from the surrounding glassy (but not completely metamict) zircon (ED spectrum 1, anal. 1). The low Si content of the crack filling 
Metamict zircon from Mozambique 193

Table 7. Microprobe analyses of zircon No. 4. Specimen LM 4368 compared with naegite and colloidal malacon analyses.

\begin{tabular}{|c|c|c|c|c|c|c|c|}
\hline & 1 & 2 & 3 & 4 & 5 & 6 & 7 \\
\hline $\mathrm{SiO}_{2}$ & 30.4 & 28.7 & 19.4 & 29.2 & 29.7 & 25.98 & 30.37 \\
\hline $\mathrm{ZrO}_{2}$ & 44.6 & 56.8 & 51.1 & 57.2 & 57.5 & 41.04 & 49.95 \\
\hline $\mathrm{HfO}_{2}$ & 3.29 & 3.45 & 3.10 & 3.95 & 3.94 & & \\
\hline $\mathrm{Al}_{2} \mathrm{O}_{3}$ & 0.58 & 0.49 & 2.89 & 0.96 & n.d. & 7.45 & $\operatorname{tr}$ \\
\hline $\mathrm{FeO}^{*}$ & 1.96 & 0.51 & 1.52 & 1.26 & 1.79 & 1.62 & 1.82 \\
\hline $\mathrm{CaO}$ & 6.79 & 0.49 & 1.79 & 0.52 & 0.72 & 9.20 & 1.07 \\
\hline $\mathrm{P}_{2} \mathrm{O}_{5}$ & 0.07 & 0.08 & 0.10 & 0.03 & 0.05 & & \\
\hline $\mathrm{Y}_{2} \mathrm{O}_{3}$ & 1.17 & 1.49 & 1.66 & 0.41 & 0.63 & & \\
\hline $\mathrm{Ln}_{2} \mathrm{O}_{3}$ & 1.60 & ** & ** & ** & 1.28 & 1.31 & 5.84 \\
\hline $\mathrm{ThO}_{2}$ & 1.48 & 0.53 & 0.89 & 0.17 & 0.20 & 0.70 & 0.23 \\
\hline $\mathrm{UO}_{2}$ & 1.26 & 0.64 & 0.41 & 0.28 & 0.51 & 5.57 & 4.93 \\
\hline $\mathrm{CO}_{2}$ & & & & & & 3.16 & \\
\hline $\mathrm{Nb}_{2} \mathrm{O}_{5}$ & & & & & & & 0.53 \\
\hline $\mathrm{H}_{2} \mathrm{O}$ & & & & & & 3.80 & 4.99 \\
\hline $\mathrm{H}_{2} \mathrm{O}^{\S}$ & 1.11 & 0.75 & $4.22 ?$ & 0.53 & 0.77 & & \\
\hline Total & 94.31 & 93.93 & 87.08 & 94.51 & 97.09 & 99.83 & 99.91 \\
\hline \multicolumn{8}{|c|}{ Cation and $\mathrm{OH}$ per cent } \\
\hline $\mathrm{Si}$ & 44.47 & 45.90 & 28.89 & 46.29 & 45.94 & & \\
\hline $\mathrm{Zr}+\mathrm{Hf}$ & 33.19 & 45.87 & 38.42 & 46.01 & 45.11 & & \\
\hline $\mathrm{Al}$ & 1.21 & 0.92 & 5.07 & 1.79 & nil & & \\
\hline $\mathrm{Fe}$ & 2.40 & 0.68 & 1.90 & 1.67 & 2.31 & & \\
\hline $\mathrm{Ca}$ & 10.64 & 0.84 & 2.85 & 0.89 & 1.19 & & \\
\hline $\mathrm{P}$ & 0.09 & 0.11 & 0.13 & 0.04 & 0.07 & & \\
\hline Y & 0.91 & 1.27 & 1.32 & 0.34 & 0.52 & & \\
\hline Ln & 0.74 & - & - & - & 0.61 & & \\
\hline Th & 0.49 & 0.21 & 0.30 & 0.06 & 0.07 & & \\
\hline U & 0.41 & 0.23 & 0.13 & 0.10 & 0.18 & & \\
\hline $\mathrm{OH}$ & 5.44 & 4.00 & $20.98 ?$ & 2.82 & 4.00 & & \\
\hline
\end{tabular}

Atomic proportion of lanthanoides based on $\mathrm{La}+\cdots \mathrm{Lu}=100$.

\begin{tabular}{lrr}
\hline $\mathrm{Ce}$ & 4.6 & 2.0 \\
$\mathrm{Sm}$ & 0.9 & 0.2 \\
$\mathrm{Eu}$ & 16.7 & 0.8 \\
$\mathrm{Gd}$ & 1.3 & 6.7 \\
$\mathrm{~Tb}$ & nil & 1.2 \\
$\mathrm{Dy}$ & 5.0 & 6.2 \\
$\mathrm{Er}$ & 13.0 & 13.0 \\
$\mathrm{Tm}$ & 7.0 & 2.0 \\
$\mathrm{Yb}$ & 43.0 & 57.4 \\
$\mathrm{Lu}$ & 8.3 & 10.9 \\
\hline
\end{tabular}

$*=$ total $\mathrm{Fe}$ as $\mathrm{FeO}, * *=$ not determined, n.d. $=$ not detected, ${ }^{\S}=$ water calculated as charge balance. Nos. $1-5$ correspond to the numbers in Fig. 6. No. 6 is a naegite analysis from Lipova et al. (1973) and No. 7 is an analysis of colloidal malacon from Turovskij et al. (1966).

is especially pronounced (compare ED spectra 3 and 1). The completely metamict parts (ED spectrum 2, anal. 2) are almost free of $\mathrm{Ca}$ and Fe. The last phase (ED spectrum 4, anal. 4) cuts through the above dessication cracks (3) and the main glassy phase (1); it is therefore the last of the phases. It contains very little uranium. Analysis 5 is from the zone of higher crystallini- 
ty following the bigger cracks surrounding the glassy areas.

Specimen Muiane 3 exhibits a completely isotropic brown phase, much like »Glaskopf». Microprobe analysis reveals that the uranium content of the brown phase is in the order of $1-2$ wt $\%$, thorium content $0.2 \mathrm{wt} \%$ and the content of REEs $0.7 \mathrm{wt} \%$.

Lipova et al. (1965) have shown by DTA that metamict zircon from the Bolshoy Olenchik pegmatite (NE Karelia) has an endothermic peak at $236^{\circ} \mathrm{C}$ and two exothermic peaks at $871^{\circ} \mathrm{C}$ and $1016^{\circ} \mathrm{C}$. They consider that metamict zircon recrystallises at $871^{\circ} \mathrm{C}$ from the oxides $\mathrm{ZrO}_{2}$ and $\mathrm{SiO}_{2}$. They assign the endothermic peak to the water loss, and leave the $1016^{\circ} \mathrm{C}$ peak unexplained.

In the zircon material from Mozambique, only an exothermic peak appears in the range $860^{\circ} \mathrm{C}$ to $940^{\circ} \mathrm{C}$, indicating the point of recrystallisation. The TG analyses show a linear weight loss in the interval $100^{\circ} \mathrm{C}$ to $800^{\circ} \mathrm{C}$, after which the curve is flattened. The weight loss from the TG curves agree well with the water determinated with Penfield's method $( \pm 0.02$ wt\%). According to data obtained from TGA, approximately $15-20 \%$ of the water was lost between $25^{\circ} \mathrm{C}$ and $150^{\circ} \mathrm{C}$ and is considered as $-\mathrm{H}_{2} \mathrm{O}$ water. Between $150^{\circ} \mathrm{C}$ and $800^{\circ} \mathrm{C}$ about $70-80 \%$ of the water was lost and is considered as nonstoichiometric $\mathrm{OH}_{2}$ interstitially in the structure. In the range $800^{\circ} \mathrm{C}$ to $1000^{\circ} \mathrm{C}$ about $0-15 \%$ of the water was lost and is considered as $\square(\mathrm{OH})_{4}$ replacing $\mathrm{SiO}_{4}$ in the zircon structure. This agrees very well with the water calculated as charge balance from the total water taken as difference (see microprobe analyses in Tables 2B and 7).

IR spectroscopy is utilised to determine the degree of metamictisation. Pellas (1965) applies it together with optical properties, DTA and $\mathrm{X}$-ray diffraction to investigate the thermal recrystallisation of metamict zircon. Deliens et al. (1977) devised a way of determining the age of zircon by studying the IR absorption band at 16.2 $\mu \mathrm{m}$. Akhmanova and Leonova (1961) show that the ratio of the logarithms of transmittance for the absorption bands at $19.2 \mu \mathrm{m}$ and 16.2 $\mu \mathrm{m}$ is proportional to the abundance of deformed $\mathrm{SiO}_{4}$ tetrahedrons. They have also established a quantitative relation between this ratio and the concentration of $\mathrm{U}$ in the zircon structure. The intensity of the $16.2 \mu \mathrm{m}$ band is lowered considerably with increasing uranium content and shifts to $15.7 \mu \mathrm{m}$ in samples with a high uranium content.

As shown previously (see Fig. 4, spectrum $X$ and Table 5), the bands at $15.7 \mu \mathrm{m}$ and $19.2 \mu \mathrm{m}$ are due to xenotime. The investigation of Akhmanova and Leonova ( $o p$. cit.), however, suggests that $\mathrm{Th}$ and $\mathrm{U}$ build up their own phases.

This investigation also shows that on heating the X-ray lines and IR absorption bands of zircon are enhanced and grow sharper, whereas xenotime is unaffected. Neither are the IR bands of zircon shifted by either heating or increasing $U$ and $T h$ contents.

Although the author does not know the original mode of occurrence of the zircon specimens in the pegmatite bodies, the shape of the specimens makes it highly probable that the metamict zircon crystals grew on the walls of open wugs. It seems reasonable to assume that the minerals crystallised in an environment rich in $\mathrm{H}_{2} \mathrm{O}, \mathrm{F}$, etc, and that this medium was also sufficiently enriched in Th and U. According to Caruba et al. (1975), such an environment facilitates the replacement of $\mathrm{SiO}_{4}$ by $\square(\mathrm{OH})_{4}$ in the zircon structure. The crystallising zircon will thus have the formula $\mathrm{Zr}\left(\mathrm{SiO}_{4}\right)_{1-\mathrm{x}}(\mathrm{OH})_{4 \mathrm{x}}$. More water is, however, present than is required by the above formula. Thus the excess water is probably present interstitially and nonstoichiometrically in the structure of the mineral. Water could have been incorporated into the growing zircon crystal simultaneously with the progress of the disordering process. 
Acknowledgements. The X-ray, IR spectroscopy and DT and TG investigations were carried out while I was at the University of Helsinki. I am indebted to Professors J. M. Correia Neves and J. E. Lopes Nunes, formerly of the University of Maputo, Mozambique, for the specimens from the university's departmental collection; to the late

\section{References}

Akhmanova, M. V. \& Leonova, L. L., 1961. Investigation of metamictization of zircons with the aid of infrared absorption spectra. Geochem. No 5, 416-431.

Caruba, R.; Baumer, A.; Mano, J. \& Turco, G., 1975. Étude comparative des propriétés respectives de zircons hydroxylés synthétiques et zircons métamictes naturels; hypothèse de genèse des malacons, Pétrologie, 1, 57-70.

Dawson, P.; Hargreave, M. M. \& Wilkinson, G. R., 1971. The vibrational spectrum of zircon $\left(\mathrm{ZrSiO}_{4}\right)$. J. Phys. C. Solid State Phys. 4, 240-256.

Deliens, M.; Delhal, J. \& Tarte, P., 1977. Metamictization and U-Pb systematics - A study by infrared absorption spectrometry of Precambrian zircons. Earth Planet. Sci. Lett. 33, 331-344.

Henneberg, W., 1846. Erdm. J. Chem. 38, 508 (ref. in Brögger 1890, Zeit. Kryst. 16, 101-115).

Hezel, A. \& Ross, S. D., 1966. Forbidden transitions in the infra-red spectra of tetrahedral anions - III. Spectrastructure correlations in perchlorates, sulphates and phosphates of the formula $\mathrm{MXO}_{4}$. Spectrochem. Acta 22, 1949-1961.

Hubin, R. \& Tarte, P., 1971. Étude infrarouge des orthosilicates et des orthogermanates - IV. Structures scheelite et zircon. Spectrochem. Acta 27 A, 683-690.

Köppel, V.\& Sommerauer, J., 1974. Trace elements and the behaviour of the $\mathrm{U}-\mathrm{Pb}$ system in inherited and newly formed zircons. Contr. Mineral. Petrol 43, 71-82.

Kulp, J. L.; Volchok, H. L. \& Holland, H. D., 1952. Age from metamict minerals. Amer. Mineral. 37, 709-718.

Lipova, I. M.; Kuznetsova, G. A. \& Makarov. Ye. S., 1965.
Professor Th. G. Sahama, of the University of Helsinki, for placing the specimens to my disposal; to Mr Boris Saltikoff, of the Geological Survey of Finland, for translating the Russian publications; to Dr. Martti Lehtinen, of the University of Helsinki, for critically reading the manuscript; and to Mrs Gillian Häkli for correcting the English.

An investigation of the metamict state in zircons and cyrtolites. Geoch. Intern. 2, No 3, 513-525.

- \& Shumkova, N. G., 1973 (Does a special variety of naegite zircon exist?) Zap. Vses. Min. Obshch. 102, 688-692 (in Russian).

Mitchell, R. S., 1973. Metamict minerals: a review. Parts I and II. Mineral. Record 4, 117-182, 214-223.

Pellas, P., 1965. Étude sur la recristallisation thermique des zircons métamictes. Mém. Mus. Nation. d'Hist. Natur., sér. C. Sci. de la Terre 12, No 5, 227-253.

Rimsaite, J., 1981. Isotope, scanning electron microscope, and energy dispersive spectrometer studies of heterogeneous zircons from radioactive granites in the Greenville structural province, Quebec and Ontario. Geol. Surv. Canada, Paper 81-1B, 25-35.

Sahama, Th. G.; von Knorring, O. \& Rehtijärvi, P., 1973. Xenotime from Morrua, Mozambique. Bull. Geol. Soc. Finland 45, 67-71.

Sansoni, G., 1966. Vergleichende Untersuchungen über die Urangehalte von Zirkonen unter besonderer Berüchsichtigung ihrer Morphologie. Chemie der Erde 25, 1-95.

Sommerauer, J., 1976. Die chemisch-physikalische Stabilität natürlischer Zirkone und ihr U-(Th)-Pb System. Dissert. Nr 5755, Eidg. Techn. Hochschuhle, Zürich.

Törnroos, R., 1982. Composition of metamict zircon from Mozambique. Bull. Geol. Soc. Finland 54, 77-83.

-, 1984. An X-ray diffraction method for determining the amount of xenotime in a zircon sample. Bull. Geol. Soc. Finland 56, 1-2, 203-206.

Turovskij, S. D.; Kim, V. F. \& Iljinskaja, G. G., 1966. (On colloidal malacon). Zap. Vses. Min. Obshch. 95, 333339 (in Russian). 